\title{
Augustinian Theological Thought and Biological Evolution
}

\author{
Olivier Perru \\ Université Lyon 1
}

\begin{abstract}
In this paper, we are looking at a philosophical approach on creation and evolution. We try to search for the possibility of an evolution in Augustine theological thought and Thomas Aquinas' works. St Augustine thinks that Earth received from God a capacity to produce plants, Thomas Aquinas claims a progressive development of plants' species in their characteristics. Concerning animals, Augustine thinks that water received the capacity to produce fishes and marine animals. In his worldview, he takes account of spontaneous generation. During the modern period, the theologians no more understood perspectives about a progressive creation: God created each living species in a Linnaean sense. An Augustinian rereading removes the opposition between evolution and creation.
\end{abstract}

Keywords: creation, St Augustine, Thomas Aquinas, evolution, spontaneous generation

\section{Introduction}

Questions linked to controversies on creationism suppose to specify knowledge of living beings. There is more than one mode to know the living. The bases of creationism and even those of Intelligent Design theory are wrong because they mistake the scientific knowledge for the theological one. Moreover, they rely on a fundamentalist conception of the holy Bible, for instance, without respecting a plurality of senses of the Scriptures. More generally, in these controversies, it is very difficult to set correctly what is science and what is not science in studying the origins of life. About creation and evolution, evolutionary biology and paleontology, philosophy and particularly metaphysics, theology, all these disciplines and their objects have legitimacy, on condition that they were well distinguished.

Philosophy often considers the living beings in their global nature and in relation to the humanity. The object of philosophy is not the same as the object of science. In philosophy, the human experience is not the scientific experiment. A philosopher recognizes the reality through a human experience, knowledge of the human life, he interrogates on causes (he inquires into causes). A philosophical approach has a goal that is taking into account the global nature of the living beings and the nature of conscious or unconscious life. Philosophy and theology involve a completely different approach as science, but we may relate epistemology with the diversity of life sciences. In this paper, we attempt to have an historical and epistemological investigation on evolution and creation, to place well and to teach well the evolution of living beings. A philosopher is able to consider science as a human experience, as a human activity and as an object. According to the philosopher, an object may be a thought or a theory, and not an object directly experimented, as for the scientist. Therefore, Evolutionary Theory may be an object for a philosopher while it is an explanation for the scientist. Creation is another object of a philosophical thought, but also it is an object of a theological approach;

Olivier Perru, Ph.D., Prof., History and Philosophy of Sciences, E.A. 4148 S2HEP, Université de Lyon, Université Lyon 1, France; main research fields: History and Philosophy of Biology, Philosophy of the Living Beings, Science and Religion. 
however, it makes no sense in a scientific reasoning. Thus, our subject is to show that there is no opposition between Evolutionary Theory and metaphysical or theological conceptions on God and creation. We suppose that the philosopher has some abilities to drive a critical inquiry about evolution and creation.

In this paper, we are looking at a philosophical approach on creation and evolution. We try to search for the possibility of an evolution in Augustine theological thought and Thomas Aquinas' works. Fundamentally, the theological thought of St Augustine supposes that God places in the world, many causal reasons of all the living beings. These causal reasons are gradually going to allow the development of living species. This way of thinking is compatible with a certain evolution. During the 5th century, St Augustin could not imagine a biological evolutionary theory; however, as his contemporaries, he admitted the spontaneous generation, which allowed the hatching of new individuals and new species. A great difficulty arises for the creation of man, where we have the impression that St Augustin returns to a very literal reading of the story told in the Bible. Therefore, it is more difficult to envisage the human evolution by basing itself on the Augustinian thought. During the 13th century, Thomas Aquinas resumes quite these questions in the Summa Theologiae. He reviews and faithfully explains St Augustine's assertions. He globally follows Augustine as regards the vegetable and animal world, but he exposes the creation of man in a theological verticality, which makes more difficult an evolutionary approach of the body.

\section{Creation and Creationism}

Faced to creationism, a philosophy may lead us to distinctions between a biological analysis of organism and another level of life analysis (Perru 2010). A good philosophy claims that a philosopher has to discuss on human life, he is able to look for the existence of causes in the human life. Normally, the end of a philosophical thought is a natural theology with the question of the existence of a Creator called God. It is essential to do the difference among biological analysis, philosophical analysis, and theology. That is the condition of a good comprehension of the problem creation-evolution. A philosopher tries to show that there is no opposition between the claim of a biological evolution and a specificity of the human being or his relation to the First Being.

What is the creationists' mistake? They link the initial creative activity of a powerful God and the existing living species. This is absurd. How can we put on the same level a theological viewpoint about creation and biological present species, or even human biological life? This is an obvious epistemological distortion.

Yet the misunderstanding between the so diverse creationist movements and the physical and natural sciences is not reducible in an opposition claimed between science and religion. Firstly, there is a question of status of the Holy Scriptures in the revealed religions. How to read and to interpret the narratives of creation? In the Christianity, in the Roman Catholic Church or in the Protestant confessions, in the 17th or 18th centuries, the reading of the Book of Genesis tends to become not only literal but also textual. It excludes the metaphor and supposes an unambiguous language, a nominal description of events. Therefore, during the 18th century, each Catholic had to consider word for word the narrative of the Genesis concerning the creation of the world in seven days. The protest of loyalty of Buffon in this vision of the world is understandable, not because he subscribed to it; however, he only tried to avoid a conflict with the catholic hierarchy, even though he tried to introduce a pre-evolutionist vision of the nature and the life (Buffon 1753, 378-83). ${ }^{1}$

However, it seems important to go back to the theology of Thomas Aquinas (13th century) to discover a much wider approach of the Word of God, and especially the narratives of creation, in the catholic tradition. 
According to Thomas Aquinas, the literal meaning of the Holy Scriptures implies the metaphor in the reference to the reality. The literal meaning is not thus an unambiguous meaning, which would give a direct access to the creation of the world. The creation by God of the Universe and the alive represents an act, which concerns exactly the origin of the material. Contrary to the fact that think the creationists, this act leaves a freedom with the action of the second causes; the creation does not exclude later transformations of the living beings, even living species, thus, it does not exclude the appearance of new forms of life. St Thomas, who could know nothing of an evolution of the life, gives a certain opening in this viewpoint, we shall see how. He asserts a creative God and a providence at the origin of any things and of any life, what is compatible with a material development, a succession of the forms of life. The understanding of the six days of the creation owes to Augustine's comments on the Book of Genesis a lot; it sends back to a metaphoric sense of the word "in the daytime.” There are thus spaces of freedom left by the theological Sum in a reading of the Genesis and the Fathers of the Church. Here this reading turns out less restrictive than the one who will be effective, during the Contre-réforme; however, we have not the same freedom of mind as regards the creation of the man and the original sin there.

Moreover, Christian theology has deepened the idea that there are autonomous secondary causes in the world. Christian God is not a Mechanic, present in all the events or in all the details; his Providence uses secondary causes. Theologians may specify an autonomous physical world, even if they believe that God created this world. At the beginning of the 18th century, Malebranche thinks that the world has been arranged with natural laws, directly by God. Malebranche believes in a God moving the world. Nevertheless, after Malebranche (1638-1715), philosophers and scientists understand this physical order as more and more autonomous. During the enlightenment, the philosophers preserved the order of the world but they excluded or limited the divine action. On this autonomy are based the autonomy and the objectivity of modern sciences.

\section{The Contribution of Augustine and Thomas Aquinas}

\subsection{What Is Creation}

Today, in an evolutionary context, it is difficult to speak about the creation of man: The body of man arises from material, from an anthropoid organism. However, we have to avoid doing a trial of concordism too. There is always a challenge to the believer to attempts to speak about creation in evolution. Augustine and Thomas Aquinas always distinguished the raw material, created by God from what we call "creation” of the living beings. According to their thought, it is possible to think that the diverse living species are potentially present in the creative act and so, during the time of creation. With their definitive shape and characters, these species would be also consequences of a biological development. According to Augustine and Thomas Aquinas, the Creator should have called to existence the diverse living beings, which were already potentially present in the world, firstly plants, then animals.

Some authors ask many questions about Augustine and evolution since the beginning of the 20th century. Henry Woods wrote "Augustine and Evolution" in 1924 and Mary Keenan published a paper entitled "St Augustine and Biological Science” in Osiris, in 1939 (Woods 1924; Keenan 1939). After the war, in 1946, Kevin Guinagh published "St Augustine and Evolution” in The Classical Weekly (Guinagh 1946). Kevin Guinagh asks some questions on St Augustine: "Does Augustine teach that organic forms arose from inorganic matter? Is he a transformist? Does he believe that from simpler forms of life more complex forms evolved in 
the passage of time? Does he believe that one species gave birth to another and different species?” Here the difficulty is to transpose some evolutionary notions to the theological Augustinian framework. So these questions are more or less biased and we need to be careful in this discourse. Guinagh wrote again:

Let us take up the first question—Was Augustine a transformist? We are quite safe in immediately deciding that he was not. He believed in spontaneous generation, technically known as a biogenesis, but that was a scientific error of his day. Vergil taught the same doctrine, when he showed how life was produced in the form of maggots which took their origin from a carcass allowed to rot in the fields. Lucretius was reminded, very probably, of the same possibilities when he observed that earthworms came out of the ground after a rain. (Guinagh 1946, 28)

Following the order proposed by Genesis 1 and considered as revealed, Thomas Aquinas approaches the question of the creation of plants in the third day of creation. This vegetable production presupposes the "gathering of waters" (S.T. I, 69, 1), that is, the distinction between dry ground and water, with the aim of the appearance of plant life. ${ }^{2}$ The absolute priority of the formation of plants on animals can amaze us but it corresponded, not only to the biblical thought, but also to the Aristotelian order. Since Antiquity, we considered that plant life preceded animal life. This viewpoint where the living being differs in successive degrees of life is far from being stupid: At present, in Evolutionary Theory, plants appear before animals as far as it supplies with some oxygen. Certainly, for quite a long time, we cannot anymore see a first stage of life in the superior plants. Augustine thinks that the Earth received from God himself the power to produce plants. God did not more intervene directly; that is always matter of autonomy of the secondary Causes. St Thomas writes:

However, for the production of plants, Augustine doesn't think the same thing as the other Fathers. These last-mentioned teach that plants have been immediately produced according to their species, during the third day, as the literal sense of the Genesis seems us indicate. Augustine claims that, at this time, the Earth was only pointed out as the productive cause of grass and wood; the Earth received a capacity to produce them... (G.L. VIII, 3 and V, 5)

The passage of the Genesis quoted here to establish St Augustine's opinion is Gn 2, 4: God, creating the sky and the earth in the same day, creates at the same time plants "before they had grown."

Augustine writes:

But as trees crashed in the paradise belonged to these species which already the earth had produced in the third day, it still produced them at their time: because these plants produced by the earth, as tells it the Scriptures, had well been created then in the earth by way of causes. In other words, at this time the earth had received the latent power to produce these plants, as now even, by virtue of the same power, the earth makes germinate such trees at their time. (S.T. I, 69, 2)

This passage is one of the most eloquent where St Augustine asserts a progressive development of vegetables, in their appropriate order, in measure of the succession of times. He is also ambivalent, because we do not know if it is about a development having the slowness of an evolution in the current biological sense; or is it about something similar in the current seeding of plants in the earth? (In this case, where from came seeds?)

According to Thomas Aquinas, God does not intervene in his creation for each species; he potentially creates some living beings, which spread all over the Earth. This viewpoint of Thomas Aquinas seems to be compatible with the evolutionary theory since plants propagate and evolve at their own rhythm thanks to a fecundity attributed by St Thomas to the Earth from the beginning ("the power to produce them"). In the thought of Augustine and Thomas Aquinas, God would not create immediately the plants species after species, during the third day. This is a very difference with the viewpoint of "the other fathers." Thomas Aquinas writes: 
In the first days, God gave a dignity of causes to the creatures. Then, he rested. However, he did not stop administrating the created world by his providence but his action involved taking care to propagate all the beings. Therefore, to produce plants is a work of propagation. He probably did not make growing the plants during the third day. He just gave the fecundity to the Earth in order to create the plants. (S.T. I, 69, 2).

St Thomas also quotes the viewpoint of the Greek Fathers who consider that the reproduction of plants involves "the generation of similar species by beforehand existing species" (S.T. I, 69, 2). It is not any more in the order of the creation and this expression is a little puzzling. Are they similar species or same species? It seems that this reading of the other Fathers of the Church by Thomas Aquinas insists on the fixedness of the species. We would thus have a reading made by the Greek Fathers and insisting on the fixedness, the stability of the species produced during the work of six days and an Augustinian interpretation where the plant life is given to the earth as potentiality calling a distribution and later developments. ${ }^{3}$

It is impossible to throw contemporary debates over a medieval paper as St Thomas' theological Sum. However, we can accept two possible interpretations of the Genesis. One of them sets the creation of God at the first beginning, what is determining to make up the Earth and for development of life (Augustine). The other one is limited to a textual reading of the Bible and to a steady state of created living species (Greek Fathers). In his spiritual freedom, Thomas Aquinas accepts these two possibilities, but he is more in sympathy with Augustine. Thomas Aquinas is not a creationist as some American fundamentalists today, for him God has not fixed the Creation in a steady state, at the beginning. He has full freedom to think some later transformations as autonomous natural phenomena. However, these phenomena remain relative to the divine government.

\subsection{The Appearance of Life}

Concerning animals, Augustine considers land animals, which can fly, not flying land animals and aquatic animals. The not flying land animals are subdivided into four groups, according to their type of reproduction. Mary Keenan writes:

From the above classification it is clear that Augustine differentiated three types of reproduction: sexual, asexual, and spontaneous generation. Spontaneous generation, he believed, occurred in a number of lower animals, produced from putrefying substances. Among these, there is special mention of worms, which are bred in fruit and wood, flies, bugs and fleas. These were supposedly generated more quickly in heat than in cold. Later, however, they reproduced sexually. Many animals, both aquatic and land, he states, reproduce asexually; the bee and the frog are cited as examples. Bees "do not conceive the seeds of their young by copulation, but gather them with their mouths as they lie scattered over the earth." Other animals, "though they themselves sprang up without any union of parents," later reproduce by sexual means. (Keenan 1939, 594)

The work of the fifth day refers to the creation of birds and fishes. Here, we find again the disagreement between Augustine and the other fathers. Thomas Aquinas wrote:

We have to observe that, as Augustine differs from the other fathers about the production of plants; he even disagrees with them about the production of fishes and birds. The other fathers claim that birds and fishes have truly been created during the fifth day, whereas Augustine maintains that the waters have only got at this time the power to produce them. (S.T. I, 71)

St Augustine indeed wrote: "On the fifth day, because they border the sky and the air, waters produced their inhabitants in the Word of God, that is all which swims and which flies. They potentially produced them, in the numbers which develop these beings, according to the stages settled by their future in the time." ${ }^{4}$ So, there is well some progressive development of fishes and birds, according to a mathematical and biological model. 
The first objection one can raise against a textual reading of the Bible is that the waters have no ability to produce all the fishes and birds. Nevertheless, if the aquatic element could produce some living beings, it should be coherent with the spontaneous generation theory. Thomas Aquinas confirms Augustine's viewpoint, according to which animals existed only virtually, at the time of their production. St Thomas defends the Augustinian theory, explaining that animals virtually exist either by a process of sexual reproduction or by the spontaneous generation, in order to assert that God has created these animals. In fact, it is necessary and sufficient that God put "a power to produce them" in the initial substance at the beginning. This same argumentation partly can help us challenge creationists and materialistic ideologists. The question of an ultimate origin of the physical world will always arise and St Augustine's theory pleads for a discreet creative God, having arranged initially the material and its properties so that it can unwind all the productions of the life during a long time. This theory is still able to seduce today, it seems to be able to ally creation and evolution. Jean-Michel Maldamé tells us:

The term of creation must carefully be distinguished from the term of transformation. This one indicates an action, which changes the first data... Strictly, the creation is not a transformation; it is production out of nothing. However, as in a useful and beneficial transformation, there is an appearance of a certain novelty, we use the term of creation to name a simple transformation. Thus there are two senses of the word and both scientists and believers often pass from a sense to the other one. (Maldamé 2007, 11)

St Augustine and St Thomas Aquinas consider God as a Creator, but a Creator who gives autonomy to processes which themselves spread out; so, they give to science and metaphysics explanatory possibilities of life and living beings. However, the God of Augustine is not an intelligent designer. He initiates a process of which he guarantees autonomy. A last remarks about this text: "St Thomas Aquinas does not decide between Augustine's viewpoint and the thought of the "other Fathers;" but he very agrees with the first. I think that is enough to show a real wideness in the reading of the Genesis, during the 13th century concerning creation of the living world. It is enough to show a certain width of sight in the reading of the Genesis during the 13th century, at least as regards the creation of the living world. In any case, according to Augustine, the creation does not consist in giving a shape to a material. There is no raw material devoid of shape because to lack shape, this is not to exist. About the creation, we can read in the Encyclopedia St Augustine:

It is rather the fact to give the being to a living system intended to grow towards beauty and order even if this beauty and this order are not completely obvious at some point. Therefore, according to Augustine, the temporal character of the world is axiomatic: it is a world in movement, a set of processes where the possible come true. He particularly develops this idea in De Genesi ad litteram (VI, 14-17 and IX, 17) through the concept of causal or seminal reasons (rationes causales aut rationes seminales), terms which are difficult to translate in an adequate way, but which express the power of development, which contain the created things. However, it does not mean that things are simply created with an immanent power of development and that their history is only displaying what they were since the beginning as natural process. In fact, rationes represent the possibility of natural development inherent to things, but they also specify the way God acts on the various elements of the world. The concept of rationes seminales allows Augustine to say that, in a sense, the creation is carried out all at once, finally (De Genesi ad litteram, V, 23, 45). Nevertheless, there is a real history of interaction between the Creator and its creation, and it is not the simple game of a pre-established necessity. (Williams 2005, 404)

Thus, the Creator is present, and at the same time, nothing prevents from thinking of a processing in the creation with a relative autonomy: "God actively watches the balance of the creation, realizing these particular possibilities for the harmony of such or such specific moment” (Williams 2005, 404). 
In fact, the seminal reasons represent a virtual creation of the species and the possibility of natural development; they have causal power and they specify a non-mechanic action of God. About these seminal reasons, a Franciscan educator, Bernard Olszewski, writes:

\begin{abstract}
In listening to the interview with the evangelical educator who advocated intelligent design, I was struck by the fact that Augustine had raised the problem sixteen hundred years ago of the apparent conflict between scriptural narration of creation and the observed changing nature of the world. Augustine was well aware of the Scriptural account of creation in the first two chapters of Genesis, but he also understood that the world in which he lived was not the exact same world that existed when Genesis was written. His solution was one of process. While stating that God created the world ex nihilo as recounted by the authors of Genesis, Augustine also pointed out that God did so through the creation of a world that contained seminal principles that are contained within matter and have causal power. Thus, all species bear the invisible potential power to become what they are not yet. Originally, God, in a single act of complete creation, provided the germinating principle of all species. For Augustine, this solved the dilemma of what scripture meant when it stated that God created the universe in six days. The systematic process described in Genesis seemed inconsistent with Augustine's view of God and impossible to hold in the literal sense, because the sun was not created until the fourth day, thus making the calculation of days impossible, as we understand it. Through his interpretation, Augustine proposed that God created all things simultaneously meaning that God implanted the seminal principles of all species at once. All species did not come into existence right away but fulfilled their potentiality over time. Although Augustine did not attempt to propose a theory of evolution of the species, the possibility for such an argument is contained within his thought. With such a framework, the Catholic college or university sees no conflict between scripture and science. (Olszewksi 2006, 31)
\end{abstract}

\title{
3.3. The Sixth and the Seventh Days
}

Let us continue with the work of the sixth day. After birds and fishes, this question exposes the creation of the diverse animals, during the sixth day, except the man to whom Thomas Aquinas will reserve specific questions later. He considered these animals as more perfected than birds and fishes on two criteria: their morphology and their generation. In reality, there is a difficulty in the purely anatomical plan. We shall easily understand that the quadrupeds, viviparous animals, are placed at the top of the animal hierarchy; why do we also put the reptiles in this group supposed to appear during the sixth day? St Thomas explains that in fact, the work of the sixth day determines the ground animals, while the previous day ordered the production of aquatic, marine, and air animals. Curiously, we find something similar in the Evolutionary Theory, where the animal life appears at first in the water, then on the earth. In animals created in the sixth day, are included the reptiles, who will practically remain a vague category till the end of the 17th century, more or less co-integrated with insects. St Thomas actually includes in the reptiles, "either, the animals which have no feet to rise from the ground, as snakes, or those who only have very short feet, as lizards and ants” (S.T. I, 72). This example allows again underlining the extension of the categories of kind and species according to Thomas Aquinas. As Aristotle, Thomas considers the lizard as a species of the quadruped group. On this matter, St Augustine writes:

By repeating three times according to their species, does not the sacred author invite us to distinguish three species of animals? Firstly, quadrupeds and reptiles according to their species: the Scriptures would then hint at quadrupeds, which belong to the class of the reptiles, as the lizards, star lizards and others of the same kind. (G.L. III, 11)

Let us indicate here a problem of translation: The translator committed an anachronism by translating "quae in genere sunt reptilium" by "the class of the reptiles." St Augustine's intention could not be to speak about class; this classificatory category applied to animals did not exist before the 18th century; the term genus is always used (we translate rather by kind), including to indicate the species. In the following paragraph, St Augustine explains secundum genus: 
The expression "according to their species” would be valid only where we have at the same time a power to engender and a resemblance of those who succeed to those who disappear. Nobody of them was definitely created, whether he would always have to last, or whether he would have to disappear without offspring... So, the expression according to their species would mean generating mode and would distinguish the similar individuals who derive from the same original germ and the other creatures. (G.L. III, 12)

The use of morphology and generation as criteria of perfection of the animal organism is rather delicate. St Thomas calls upon these criteria which suit well in mammals, but not at all in reptiles. The idea of an order of perfection in the creation is insufficiently supported.

With spontaneous generation, Thomas Aquinas shows us he admitted a possible appearance of animal species from a living being or from a preexistent and less noble material. He writes:

Generation of a living being is corruption of another, during the first production of the creatures, corruption of a less noble creature may have generated a nobler creature. So, animals who are born from corruption of plants or inanimate beings may be have generated, but that's not the same thing for those who are born from corruption of animals, they rather may have been only virtually generated. (S.T. I, 72)

The last sentence, a little enigmatic for us, shows well what we imagined of the spontaneous generation: From decomposition of the organic material and from the inanimate material, animals would have been generated at the time of the "primitive production of beings." Curiously and in the same logic, according to Thomas Aquinas, spontaneous generation supposed that some animals (insects) came from decomposed flesh, but not from other animals. In 1668, Francesco Redi demonstrated that this belief was wrong, because maggots came from the eggs of flies.

There is another interfering belief, the idea that in the state of original justice, the death does not exist. St Thomas thus makes an acrobatic reasoning based on the act and the power to assert that these animals existed all the same, but potentially, because the animals of which they would have to come did not experience any corruption. We have here a good example of the unlikeliness of a religious speech connected to a conception according to which the death was able to enter the world only because of the fault of a man (consequences of the original sin). St Thomas only repeats what St Augustine had written. According to Augustine, the decomposition (especially for animals) is "a consequence of the punishment which made of us mortal beings" (G.L. III, 14). Augustine does the same reasoning for pests: "Should not you rather think that, at first created harmless, they [the venomous and dangerous animal species] remain harmful only once committed the sin?” (G.L. III, 15)

About the seventh day (question 73), an interesting objection concerns exactly the appearance of the new species after the work of six days and because of the spontaneous generation. Thomas Aquinas writes the objection: "After the 7th day, many things have been created and many individuals have been produced. New species appeared, principally among animals generated by putrefaction” (S.T. I, 73, 1, d. 3). In fact, in his answer, St Thomas resumes the idea of a preliminary existence of animals existing today, during the creation; that it is about animals produced by the sexual reproduction or about those, which he considered as spontaneously produced. Thomas Aquinas considers that many animals virtually and materially preexisted "as effects in their cause, so individuals generated at present preexisted in the first individuals of their species" (S.T. I, 73, 1, ad 3m). About the appearance of new species, Thomas Aquinas writes: "New species themselves, if they really exist, have also virtually preexisted in the beings able to produce them. For instance, animals that are born from putrefaction are produced by a virtue that stars and elements originally received, however if these animals constitute new species" (S.T. I, 73, 1). This notion of potential pre-existence of new species, "as the 
effects in their cause," allows to envisage a kind of evolution (St Thomas could naturally have no idea of it) and his compatibility with the creation. This way, the Augustinian frame of thought resumed by St Thomas allows raising a creationist obstacle, the idea of immediate and definitive creation of the species.

In question 74 (article 1), Thomas Aquinas resumes the assertion of Augustine, according to whom the creation has an essential character, to be outside the time. According to St Augustine, the work of creation belongs to the production of the material nature and the spiritual nature in a formless state. These two things are outside time, as this holy doctor himself tells us (Confessions, XII, 12). This is why their creation is placed before the existence of days (S.T. I, 74, 1, ad 1m. Mc Quinn 2005, 1394). William A. Christian told us: "Creation does not fall within that series of successive events, each coming to be and ceasing to be, of which time is the measure. Creation is not an act in time. Creation is in the beginning” (Christian 1953, 3). So, this would make no sense to bring into conflict the creation and phenomena highlighted by biologists, because the creation as such escapes the spatiotemporal frame.

With a very high accuracy, Thomas Aquinas asks a question about the nature of days: Have we to take them in the literal sense, either in the metaphoric sense, as thinks St Augustine? For Augustine, the duration of the days of the creation, their resemblance with the days of the week are very uncertain; every day could represent not a unit of time, but the knowledge which have the angels of God's work. The day is metaphorically the light of the angelic knowledge, which allows them to grasp the effects and the characteristics of God's creative action. "Other Fathers" see much more a succession of time and effective productions in these seven days. Saint Thomas tries to point out that there is not such a contradiction as of what we could think.

\section{Conclusion}

Augustine and Thomas Aquinas are completely distant from a reduction of the word of God to the letter of the Scriptures. This theological work has no relationship with a creationist viewpoint as this of some protestant denomination in the United States for example.

A negative relationship between evolution and religious consciousness do not base on scientific results; some believers root it in the reading of the Bible. Here is a paper of Lee Meadows:

Joanne has dreaded the evolution unit for several years now. Science has always been her favorite subject in school, but she has often felt tension between her faith and her love for science. Sometimes, she even feels guilty. She goes to a Baptist church where she has learned that the Bible should be read literally. She has never questioned that teaching; everyone in her life believes basically the same way. For Joanne, if the Bible says that God created the world in 6 days, that is what happened. In fact, as she imagines the creation of the world, she sees God's majesty and power at works as he shapes the world like a master designer. Joanne is just beginning to realize that her love for creation is probably the basis for her love for science. She sees science as the study of God's world, and everywhere she looks, she sees evidence of God at work. (Meadows 2007, 146)

As she thinks about taking biology, though, she is worried. She heard from older students in her church youth group how bad the evolution unit is. One of the sophomores talked about an argument on creation versus evolution in the biology class. He said that the teacher got mad and finally settled the argument by telling the class, "You have to choose between science and faith, you can’t have both.” After hearing that at youth group, she asked her young pastor about some of her worries. He said, "You just have to believe, Joanne. You cannot think all this through. God wants us to believe in him, not look for proof, not in science or anywhere else" (Meadows 2007, 146). 
This text underlines some difficulties of fundamentalism, especially when we add the protestant principle Sola fide, sola scriptura. Fundamentalists see God immediately and anywhere at work. This figure of an anywhere intervening God is obligatory in conflict with scientific biological models. Thomas Aquinas' God does not intervene anywhere but a man of the middle age saw him as the Creator. Today, it is difficult for us to understand what Thomas Aquinas named "ornament work." The living beings do not exist only to decorate the world! Faced to an extreme diversity of viewpoints on natural world and living beings, the solution is doubtless to accept some different approaches of the same object in biology, philosophy and theology in order to get coherence and complementarities. About evolution, biological discoveries do not exclude other analysis levels; they do not exclude an initial creative act or providence. Scientific methods cannot reach metaphysical entities, if they exist. Scientists can only speak about events produced at random. Theological and scientific knowledge are specifically different, but they are compatible.

Creationism may have a source in a protestant view on the sacred scriptures, but also another source in a fixist mentality, which become harder during the 18th and 19th centuries. In the reading of the biblical text, the good keys had been lost. In fixism or in creationism, there is neither autonomy nor evolution of man or living beings. God would be a technician inventing some machines. At the end of the 19th century, the opposition between Christians and scientism produced an opposition between an anti-evolutionary attitude and the evolutionary scientists. This opposition (which is finally an opposition between faith and reason) was not right. Beyond these oppositions and confusions, we still have today to give to our students a philosophical training and a good knowledge in the occidental culture.

\section{Notes}

1. "S’il était une fois prouvé... s'il était acquis que dans les animaux, et même dans les végétaux, il y eût, je ne dis pas plusieurs espèces, mais une seule qui eût été produite par la dégénération d'une autre espèce; s'il était vrai que l'âne ne fut qu’un cheval dégénéré, il n’y aurait plus de bornes à la puissance de la nature et on n'aurait pas tort de supposer que d'un seul être, elle a su tirer avec le temps tous les autres êtres organisée... Mais non, il est certain, par la révélation, que tous les animaux ont également participé à la grâce de la création, que les deux premiers de chaque espèce et de toutes les espèces sont sortis tous formés des mains du Créateur, et l'on doit croire qu'ils étaient tels alors, à peu près, qu'ils nous sont aujourd'hui représentés par leurs descendant.” Georges-Louis Leclerc de Buffon, Histoire naturelle générale et particulière avec la description du cabinet du Roi, tome 4 (Paris: Imprimerie royale, 1753), 378-83.

2. 'Then God said, 'Let the waters below the heavens be gathered into one place, and let the dry land appear;' and it was so. God called the dry land earth, and the gathering of the waters He called seas; and God saw that it was good...” (Genesis, 1; 9-10)

3. In this question of the production of plants, Thomas Aquinas uses alternately texts borrowed from both narratives of the creation, Genesis 1 and 2, and he confronts them. In the first narrative, we can read: “And God said, Let the earth bring forth grass, the herb yielding seed, and the fruit tree yielding fruit after his kind, whose seed is in itself, upon the earth: and it was so. And the earth brought forth grass and herb yielding seed after his kind, and the tree yielding fruit, whose seed was in itself, after his kind: and God saw that it was good" (Genesis, 1; 11-12). We find the beginning of the verse 11 in the St Thomas' second quotation, q. 69 , art. 2. The second narrative sends back us at the first moment of creation. "These are the generations of the heavens and of the earth when they were created, in the day that the Lord God made the earth and the heavens, and every plant of the field before it was in the earth, and every herb of the field before it grew: for the Lord God had not caused it to rain upon the earth, and there was not a man to till the ground" (Genesis 2; 4-5). In a variation of translation near, we find the beginning of the verse 5 in the St Thomas' first quotation, q. 69, art. 2.

4. See St Augustine, De Genesi ad litteram, V, 5. 


\section{Works Cited}

Augustine (St). “La Genèse au sens littéral: De Genesi ad litteram (G.L.).” Bibliothèque augustinienne Vol. 2. Paris: Desclée de Brouwer, 1972.

Buffon, Georges-Louis Leclerc de. Histoire naturelle générale et particulière avec la description du cabinet du Roi tome 4. Paris: Imprimerie royale, 1753.

Christian, William A. “Augustine on the Creation of the World.” The Harvard Theological Review 46.1 (1953): 1-25.

Guinagh, Kevin. “St Augustine and Evolution.” The Classical Weekly 40.4 (1946): 26-31.

Keenan, Mary Elizabeth. “St. Augustine and Biological Science.” Osiris 7 (1939): 588-608.

Lee, Meadows. "Approaching the Conflict between Religion and Evolution.” Teaching about Scientific Origins. Eds. Leslie S. Jones and Michael J. Reiss. New York: Peter Lang, 2007. 145-57.

Maldamé, Jean-Michel. "Préface.” Delsol, Michel. Darwin, le hasard et Dieu. Paris: Vrin, 2007.

Mc Quinn, John. “Temps.” Saint Augustin, la méditerranée et l’Europe, IV -XXI siècles. Ed. Marie-Anne Vannier. Edition française. Paris: Cerf, 2005. 1388-97.

Olszewksi, Bernard. “Critical Intellectual Inquiry at Catholic Colleges.” Academe 92.1 (2006): 30-32.

Perru, Olivier. La création sans le créationnisme? Paris: Kimé, 2010, in French.

Thomas Aquinas (St). Summa Theologiae, Prima Pars. Madrid: Biblioteca de autores cristianos, 1955 (S.T.).

Williams, Rowan. “Création.” St Augustin, la méditerranée et l'Europe, IVe-XXI siècles. Ed. Marie-Anne Vannier. Edition française. Paris: Cerf, 2005. 404-8.

Woods, Henry. Augustine and Evolution. University of Santa Clara, California: The Universal Knowledge Foundation, 1924. 